\title{
Pendidikan pendahuluan bela negara melalui pendidikan kewarganegaraan
}

\author{
Asep Dahliyana ${ }^{1}$, Encep Syarief Nurdin ${ }^{2}$, Dasim Budimansyah ${ }^{3}$, Ace Suryadi ${ }^{4}$ \\ 1,2,3,4 Program Studi Pendidikan Umum dan Karakter Universitas Pendidikan Indonesia, Bandung Indonesia
}

\begin{abstract}
ABSTRAK
Pendidikan Kewarganegaraan di Indonesia memiliki beberapa fungsi salah satunya sebagai pendidikan pendahuluan bela negara. Namun dalam praktiknya, proses pembelajaran Pendidikan Kewarganegaraan di perguruan tinggi masih belum menemukan formula yang sesuai dengan konsep pendidikan bela negara untuk warga negara sipil. Penelitian ini bermaksud untuk menjelaskan peranan Pendidikan Kewarganegaraan dalam konteks pendidikan pendahuluan bela negara di perguruan tinggi. Metode yang digunakan dengan pendekatan mix method dengan the dominant less dominant antara wawancara dan survey yang dilakukan kepada 400 peserta didik dan 8 dosen. Proses pengambilan data dilakukan pada peserta didik Universitas Pendidikan Indonesia yang berasal dari 10 (sepuluh) program studi yang berbeda. Hasil penelitian menunjukkan bahwa Pendidikan Kewarganegaraan di perguruan memiliki pengaruh terhadap nilai-nilai bela negara dengan kisaran yang berbeda. Hal tersebut dikuatkan dengan hasil wawancara bahwa Pendidikan Kewarganegaraan dapat meningkatkan kecintaan dan motivasi untuk membela negara namun masih dalam tataran pemikiran berbentuk pengetahuan belum pada tataran tindakan. Oleh sebab, praktik dalam pendidikan pendahuluan bela negara tergantung dari perilaku peserta didik itu sendiri. Hal tersebut memiliki implikasi bahwa Pendidikan Kewarganegaraan sebagai pendidikan pendahuluan bela negara untuk warga negara sipil syarat nilai tanpa makna yang tidak berpengaruh terhadap perilaku warga negara sipil secara aktual karena masih berada pada tataran konsep dan pengetahuan peserta didik semata.
\end{abstract}

\section{ABSTRACT}

Civic Education in Indonesia has several goals, one of which is as primary education for the country's defense. Nevertheless, in practice, the Civic Education learning process in tertiary institutions has not yet found a formula that is in line with the concept of state defense education for civilians. This study intends to explain the role of Civic Education in the context of primary education in state defense in tertiary institutions. The mixed-method approach method with the dominant less dominant between interviews and surveys conducted to 400 students and eight lecturers. The data collection process was carried out on the students of Universitas Pendidikan Indonesia, who came from 10 (ten) different study programs. The study results illustrate that Civic Education in universities influences the values of defending the country with different ranges. The interview results confirmed that Civic Education can increase the love and motivation to defend the country but still at the level of thought in the form of knowledge, not at the level of action. Therefore, practice in primary education in state defense depends on the behavior of the students themselves. It implies that Civic Education as primary education for civilians' defense is a condition without meaning that does not affect civilians' actual behavior because it is still at the students' concepts and knowledge only.

\author{
Sejarah Artikel \\ Diterima : 31 Oktober 2019 \\ Disetujui: 12 Maret 2020
}

Kata kunci:

bela negara, pendidikan kewarganegaraan, nasionalisme, patriotisme

\section{Keywords:}

defend the state, civic education, nationalism, patriotism

\section{Pendahuluan}

Pendidikan pendahuluan bela negara di perguruan tinggi melalui Pendidikan Kewarganegaraan dapat dijadikan sebagai wahana untuk meminimalisir berbagai bentuk ancaman, tantangan, hambatan, dan gangguan bagi negara Indonesia (Gredinand, 2017, hal. 1). Salah satu bentuk pendidikan pendahuluan bela negara di Indonesia yang dilaksanakan melalui pendidikan kewarganegaraan untuk warga sipil memiliki tujuan untuk menciptakan warga negara yang dapat diandalkan oleh bangsa dan negara (Suharyanto, 2013, hal. 192). Namun pada praktiknya, Pendidikan 
Kewarganegaraan menemui kendala dalam menemukan formulasi tepat untuk menciptakan warga negara yang mempunyai cinta tanah air, rela berkorban, sadar berbangsa dan bernegara, setia terhadap Pancasila sebagai ideologi negara, memiliki kemampuan awal bela negara baik secara fisik maupun non-fisik (Gredinand, 2017, hal. 25).

Keadaan tersebut menurut tulisan Randall (2017) karena pendidikan kewarganegaraan berada pada paradigma baru yang merupakan bentuk anti-pendidikan kewarganegaraan di Amerika yang sudah dikhawatirkan oleh banyak pengamat akan melenyapkan kewarganegaraan tradisional. Hal itu dibuktikan dengan banyaknya para pendukung pendidikan kewarganegaraan baru yang berisi kosakata kamuflase dari istilah yang terdengar menyenangkan dengan tujuan untuk mempersiapkan peserta didik menjadi aktivis sosial dan politik. Pendukung Kewarganegaraan baru menggunakan "demokrasi" untuk "tujuan sosial dan ekonomi radikal, sesuai dengan keyakinan yang berkisar dari John Dewey ke Karl Marx" (Randall, 2017, hal. 20). Akibatnya, sampai saat ini meski beberapa penelitian mengungkapkan Pendidikan Kewarganegaraan mampu mempengaruhi warga negara dalam hal nilai tetapi secara praktik baik itu materi, metode, dan evaluasi bahkan sumber daya manusia untuk mendidik masih menjadi misteri yang belum terpecahkan. Hal tersebut karena Pendidikan Kewarganegaraan merupakan bentuk dari kehendak negara untuk menciptakan warga negara yang baik yang tidak akan bisa lari dari indoktrinasi.

Padahal di beberapa negara maju, wujud bela negara diaktualisasikan dengan adanya wajib militer seperti Korea Selatan. Menurut Kwon (2000), dengan dilaksanakannya pendidikan pendahuluan bela negara melalui wajib militer tersebut, warga negara yang ikut berpartisipasi telah memainkan peran dalam membangun kewarganegaraan, kebangsaan, bahkan sampai pada kejantanan (Hal. 26). Temuan tersebut diperkuat oleh Hwang (2018, hal. 12) di mana secara historis, wajib militer yang diselenggarakan oleh Korea Selatan telah memproduksi warga negara yang mampu berperan aktif dalam memperbaiki batas-batas diskursif bangsa bahkan memiliki pemahaman militer tentang kewarganegaraan dan keamanan nasional.

Selain Korea Selatan, Norwegia merupakan negara yang mengimplementasikan wajib militer untuk warga negaranya. Dari Kosnik (2017, hal. 457) disebutkan bahwa wajib militer di Norwegia merupakan strategi pertahanan pertama yang berperan untuk melaksanakan misi-misi seperti pertahanan teritorial dan keamanan perbatasan. Lebih lanjut Kosnik memprediksi, bahwa wajib militer akan tetap menjadi alat strategi bagi negara-negara kecil pada abad 21, mengingat wajib militer dapat menyelesaikan berbagai tugas yang disesuaikan dengan kebutuhan keamanan nasional negara.

Bahkan di Singapura, hasil dari wajib militer memperlihatkan prajurit nasional dengan kualitas disiplin, tanggung jawab, semangat tim, dan kebugaran fisik yang mumpuni. Keadaan tersebut dimanfaatkan secara positif oleh peserta wajib militer dalam kehidupan sipil yang selanjutnya menjadi ciri khas dari tenaga kerja Singapura (Nair, 1995, hal. 93). Hal tersebut menurut Randall (2017, hal. 22) membuktikan bahwa keterlibatan sipil sangat berarti dalam membangun negara. Hasil dari beberapa penelitian di atas memberikan gambaran bahwa penyelenggaraan bela negara diaktualisasikan langsung dengan membuat keterikatan antara warga negara dengan negara dengan menjadi bagian yang secara emosional menjadikan terikat karena adanya visi-misi yang tegas dalam upaya pendidikan pendahuluan bela negara.

Keadaan yang berbeda diungkapkan dalam kajian Mellors \& McKean (1984) bahwa wajib militer pada perkembangannya dipertanyakan dalam hal pendanaan dan strateginya di Eropa Utara (hal. 25). Hal tersebut disebabkan, terjadinya peningkatan atas pengakuan keberatan yang berasal dari hati nurani warga negara yang dipicu oleh liberalisasi layanan wajib militer. 
Memperhatikan dan menganalisis dengan saksama fenomena tersebut, menurut Anggoro (2003, hal. 3), hal yang harus dipikirkan dan dianalisis saat ini bahwa ancaman dalam bentuk militer hanya merupakan sebagian dari dimensi ancaman yang mendera suatu negara pada masa yang akan datang. Oleh sebab pada perkembangannya, ancaman yang harus disikapi yaitu dengan munculnya masalah dalam bentuk human security (nir-militer). Berbeda dari perspektif sebelumnya yang cenderung melihat negara sebagai unsur yang paling penting, "human security" justru melihat pentingnya keamanan manusia. Dalam perspektif ini, kesejahteraan warga negara merupakan sesuatu yang dipandang sangat penting. Mereka dapat menghadapi ancaman dari berbagai sumber, bahkan termasuk dari aparatur represif negara, epidemi penyakit, kejahatan yang meluas, sampai dengan bencana alam maupun kecelakaan. Pendapat tersebut disambut baik oleh Tamba (2017) yang berupaya untuk menguraikan bahwa bela negara dapat dilakukan tidak hanya dengan memikul senjata tetapi untuk para peserta didik, bela negara dapat dilakukan dengan cara belajar tekun, menjaga keamanan di lingkungan masyarakat ataupun lingkungan sekolah dari ancaman yang dapat membahayakan kehidupan berbangsa dan bernegara, tidak membuang sampah sembarangan, menghormati bendera merah putih dan lagu kebangsaan, serta menolak campur tangan pihak asing terhadap kedaulatan Negara Kesatuan Republik Indonesia (hal. 333).

Dengan berpegang pada uraian di atas, dalam kerangka menunaikan hak dan kewajiban seorang warga negara yang telah dibakukan dalam peraturan perundang-undangan yang berlaku tentang bela negara untuk warga negara sipil (Undang-Undang Dasar Negara Republik Indonesia tahun 1945 Pasal 27 dan 30; Undang-Undang Nomor 39 tahun 1999 tenang Hak Asasi Manusia Pasal 68; UndangUndang Nomor 3 tahun 2002 tentang Pertahanan Negara Pasal 9; Undang-Undang Nomor 40 tahun 2009 tentang Kepemudaan Pasal 8, 23 dan 25; Keppres Nomor 28 tahun 2006 tentang Hari Bela Negara; Permendagri Nomor 38 tahun 2011 tentang Pedoman Peningkatan Kesadaran Bela Negara di Daerah; Perpres Nomor 47 tahun 2009 tentang Pembentukan dan Organisasi Kementerian Negara; dan Permenhan RI Nomor 32 tahun 2016 tentang Pedoman Pembinaan Kesadaran Bela Negara) dalam upaya menjaga keutuhan hidup bangsa dan negara (Purwaningsih, 2005). Dengan demikian, diperlukan reorientasi dan reformulasi pendidikan pendahuluan bela negara yang dapat memberikan kesadaran kebangsaan (Gredinand, 2017, hal. 25) melalui jenjang pendidikan formal yaitu melalui Pendidikan Kewarganegaraan. Lantas, bagaimanakah pendidikan pendahuluan bela negara dapat dilakukan melalui pendidikan kewarganegaraan? Oleh sebab, di Zimbabwe penyelenggaraan Pendidikan Kewarganegaraan dianggap sebagai upaya untuk mengindoktrinasi pemuda. Alasannya, konsep Pendidikan Kewarganegaraan sempit dan tidak memungkinkan untuk diimplementasikan sesuai dengan kurikulumnya. Akibatnya Pendidikan Kewarganegaraan dibayangi kepentingan lain berupa manipulasi untuk agenda politik daripada agenda kebijakan internasional (Magudu, 2012; Janmaat \& Piattoeva, 2007).

Berdasarkan uraian di atas, penelitian ini hendak mengungkap peranan Pendidikan Kewarganegaraan sebagai pendidikan pendahuluan bela negara di perguruan tinggi yang notabene sebagai salah satu bentuk perwujudan dari amanah perundang-undangan khususnya UndangUndang Nomor 3 tahun 2002 tentang Pertahanan Negara bagi masyarakat sipil khususnya melalui materi-materi yang dibelajarkan melalui Pendidikan Kewarganegaraan terhadap nilai-nilai bela negara.

\section{Metode}

Penelitian ini menggunakan dua pendekatan, kuantitatif dan kualitatif dengan pola "the dominant-less dominat design". Bagian pertama dalam penelitian ini menggunakan pendekatan kuantitatif, yakni melalui metode survey. Pendekatan kuantitatif dijadikan sebagai pendekatan yang dominan dalam penelitian ini karena tujuan penelitian untuk mengukur banyak variabel, mengetes 
hipotesis, dan membuat simpulan dari pertanyaan-pertanyaan mengenai perilaku, pengalaman, atau karakteristik dari suatu fenomena. Penelitian ini pun mengambil sampel dari suatu populasi peserta didik yang terdapat di kampus yang berada pada 10 (sepuluh) program studi pada Universitas Pendidikan Indonesia. Subjek penelitian yang dapat memberikan respons dengan baik terdapat 10 (sepuluh) kelas yang terdiri dari 4 (empat) sosial dan 6 (enam) eksak. Sementara, untuk pendekatan kualitatif, dilakukan dengan melakukan wawancara terhadap 8 (delapan) dosen pengampu mata kuliah Pendidikan Kewarganegaraan. Setelah itu dianalisis menggunakan tahapan reduksi data, penyajian data, dan penarikan kesimpulan.

\section{Hasil dan Pembahasan}

Kesadaran bela negara merupakan hal yang esensial dan harus dimiliki oleh setiap warga negara, sebagai wujud penunaian hak dan kewajibannya terhadap negara. Kesadaran tersebut akan menjadi modal sekaligus kekuatan bangsa, dalam rangka menjaga keutuhan, kedaulatan serta kelangsungan hidup bangsa dan negara Indonesia (Purwaningsih, 2005). Setiap warga negara bahkan anak muda harus memperoleh pendidikan pendahuluan bela negara (Lukman \& Audu, 2014, hal. 119). Apabila pendidikan pendahuluan bela negara tersebut untuk di Indonesia dapat dilaksanakan oleh Pendidikan Kewarganegaraan, maka setiap warga negara harus mendapatkan proses pendidikan yang di dalamnya diselenggarakan Pendidikan Kewarganegaraan. Oleh sebab, Pendidikan Kewarganegaraan dianggap sebagai katalis untuk mengembalikan kepercayaan, perdamaian, dan persatuan dalam pikiran generasi muda untuk saling pengertian, menjadi tenaga kerja yang bermartabat, hidup bersama, menjunjung kebenaran, dan menumbuhkan rasa cinta untuk hidup berdampingan (Enu, 2017, hal. 36).

Dalam konteks pendidikan pendahuluan bela negara, diselenggarakannya Pendidikan Kewarganegaraan disebabkan semakin maju suatu negara maka semakin banyak tantangan yang harus dihadapi oleh negara tersebut. Dengan arus globalisasi dan modernisasi dunia, suatu negara akan semakin mudah untuk digoyahkan, bukan hanya di negara berkembang tetapi negara maju juga mendapatkan ancaman tersebut, baik ancaman dari luar maupun ancaman dari dalam negara itu sendiri. Oleh sebab itu, suatu bangsa harus memiliki rasa nasionalisme yang kuat untuk melindungi dan membela negaranya dari negara lain yang lebih berwawasan intelektual luas (Tamba, 2017). Dalam tulisannya, Tamba (2017) menjelaskan bahwa Pendidikan Kewarganegaraan mengandung materi (bahan ajar) yang berhubungan erat dengan pembentukan sikap dan kepribadian diri seseorang sebagai seorang siswa yang memiliki budi-pekerti, etika dan moral yang baik serta cinta terhadap tanah air yang dapat mengantarkannya untuk memiliki wawasan dan kesadaran akan bela negara (Hal. 337).

Berdasarkan hasil penelitian yang dilakukan terhadap 400 orang peserta didik, materi-materi Pendidikan Kewarganegaraan yang dapat mengembangkan dan membina bela negara peserta didik adalah:

1. Ideologi nasional, identitas nasional, wawasan nusantara, wiyata mandala, ipoleksosbudhankam, sejarah perjuangan bangsa Indonesia, dan kemerdekaan Indonesia.

2. Materi nasionalisme dan patriotisme dalam perkuliahan Pendidikan Kewarganegaraan di kampus seperti kejujuran dalam berkata dan bertindak, peduli terhadap lingkungan, rela berkorban, mengesampingkan ego dan mendahulukan kepeningan umum, serta keteladanan.

Berdasarkan hasil wawancara tersebut, dapat diberikan ilustrasi bahwa Pendidikan Kewarganegaraan sebagai pembentukan sikap dan interaksi sosial yang keduanya dapat digunakan untuk mengatasi berbagai masalah seputar pembangunan baik untuk pengembangan individu maupun sosial bangsa (Lukman \& Audu, 2014, hal. 125) termasuk tentang bela negara. Akan tetapi sebelum pembahasannya semakin jauh, akan terlebih dahulu diberikan gambaran tentang konsepsi 
Pendidikan Kewarganegaraan yang dihasilkan dari penelitian Grammes (2011) pada tabel 1. Dari indikator-indikator yang disampaikan pada tabel tentang konsepsi Pendidikan Kewarganegaraan yang berlaku di suatu negara, maka dapat dipastikan bahwa Indonesia berada pada tataran pendidikan kewarganegaraan republikan. Hal tersebut disebabkan, kebijakan Pendidikan Kewarganegaraan berhubungan dengan negara yang bertujuan agar peserta didik memiliki perasaan autentik terhadap bangsa dan negara. Sebagaimana di atur dalam penjelasan Pasal 37 Undang-Undang Sistem Pendidikan Nasional yaitu Undang-Undang Nomor 20 tahun 2003 dan Undang-Undang Nomor 12 tahun 2012, serta Pasal 9 Undang-Undang Nomor 3 tahun 2002 tentang Pertahanan Negara yang menekankan Pendidikan Kewarganegaraan harus dapat membina perasaan nasionalisme dan patriotisme serta sebagai salah satu wujud bentuk bela negara yang dapat dilakukan oleh warga negara sipil.

Tabel 1.

Konsepsi Pendidikan Kewarganegaraan - Suatu Perbandingan (Joel Westheiner)

\begin{tabular}{|c|c|c|c|c|}
\hline & $\begin{array}{l}\text { Pendidikan } \\
\text { Kewarganegaraan } \\
\text { Liberal }\end{array}$ & $\begin{array}{l}\text { Pendidikan } \\
\text { Kewarganegaraan } \\
\text { yang beragam }\end{array}$ & $\begin{array}{l}\text { Pendidikan } \\
\text { Kewarganegaraan } \\
\text { Kritis }\end{array}$ & $\begin{array}{l}\text { Pendidikan } \\
\text { Kewarganegaraan } \\
\text { Republik }\end{array}$ \\
\hline Sifat Manusia & Individu & $\begin{array}{l}\text { Berafiliasi dengan } \\
\text { grup sosial }\end{array}$ & $\begin{array}{l}\text { Individu yang } \\
\text { disandingkan } \\
\text { dengan individu } \\
\text { dan kelompok lain }\end{array}$ & $\begin{array}{l}\text { Berafiliasi dengan } \\
\text { bangsa/negara }\end{array}$ \\
\hline Sifat Masyarakat & $\begin{array}{l}\text { Sekumpulan } \\
\text { individu }\end{array}$ & $\begin{array}{l}\text { Pertemuan } \\
\text { kelompok sosial }\end{array}$ & $\begin{array}{l}\text { Kenyataan di } \\
\text { mana struktur } \\
\text { kekuasaan } \\
\text { mempertahankan } \\
\text { penindasan }\end{array}$ & $\begin{array}{l}\text { Bangsa secara } \\
\text { keseluruhan yang } \\
\text { bernilai lebih dari } \\
\text { jumlah bagian- } \\
\text { bagiannya }\end{array}$ \\
\hline $\begin{array}{l}\text { Persepsi } \\
\text { Pengetahuan }\end{array}$ & $\begin{array}{l}\text { Menekankan } \\
\text { pengetahuan yang } \\
\text { bertujuan } \\
\text { membantu } \\
\text { individu bertindak } \\
\text { di ruang publik }\end{array}$ & $\begin{array}{l}\text { Menekankan } \\
\text { pengetahuan yang } \\
\text { bertujuan } \\
\text { membantu } \\
\text { kelompok sosial } \\
\text { bertindak di ruang } \\
\text { publik }\end{array}$ & $\begin{array}{l}\text { Sebuah alat di } \\
\text { tangan para } \\
\text { penindas yang } \\
\text { dapat digunakan } \\
\text { untuk } \\
\text { mempertanyakan } \\
\text { kenyataan }\end{array}$ & $\begin{array}{l}\text { Menekankan } \\
\text { pengetahuan } \\
\text { tentang entitas } \\
\text { sosial yang lebih } \\
\text { besar }\end{array}$ \\
\hline Persepsi Sikap & $\begin{array}{l}\text { Tekankan nilai- } \\
\text { nilai individualistis }\end{array}$ & $\begin{array}{l}\text { Tekankan nilai- } \\
\text { nilai yang } \\
\text { menghubungkan } \\
\text { individu dengan } \\
\text { kelompok sosial }\end{array}$ & $\begin{array}{l}\text { Dapat } \\
\text { dimanipulasi } \\
\text { untuk menjaga } \\
\text { realitas sosial }\end{array}$ & $\begin{array}{l}\text { Menekankan nilai- } \\
\text { nilai yang } \\
\text { terhubung dengar } \\
\text { individu ke entri } \\
\text { masyarakat yang } \\
\text { lebih besar }\end{array}$ \\
\hline Peran Pendidikan & $\begin{array}{l}\text { Mengembangkan } \\
\text { Keterampilan } \\
\text { Individu }\end{array}$ & $\begin{array}{l}\text { Mengembangkan } \\
\text { keterampilan } \\
\text { untuk } \\
\text { meningkatkan } \\
\text { realitas kelompok } \\
\text { sosial dan } \\
\text { tempatnya di } \\
\text { masyarakat }\end{array}$ & $\begin{array}{l}\text { Mengembangkan } \\
\text { kemampuan kritis }\end{array}$ & $\begin{array}{l}\text { Mempromosikan } \\
\text { perasaan menjadi } \\
\text { bagian dari entri } \\
\text { masyarakat yang } \\
\text { lebih besar }\end{array}$ \\
\hline $\begin{array}{l}\text { Tujuan normatif } \\
\text { Pendidikan } \\
\text { Kewarganegaraan }\end{array}$ & $\begin{array}{l}\text { Siswa akan } \\
\text { mengembangkan } \\
\text { keterampilan yang } \\
\text { penting untuk } \\
\text { bertindak sebagai }\end{array}$ & $\begin{array}{l}\text { Siswa akan } \\
\text { menjelaskan cara- } \\
\text { cara di mana } \\
\text { kelompok sosial } \\
\text { yang berbeda }\end{array}$ & $\begin{array}{l}\text { Siswa akan } \\
\text { mengembangkan } \\
\text { keterampilan } \\
\text { analitis individu } \\
\text { yang diperlukan }\end{array}$ & $\begin{array}{l}\text { Siswa harus } \\
\text { memiliki perasaan } \\
\text { autentik atas } \\
\text { kepemilikan } \\
\text { negara }\end{array}$ \\
\hline
\end{tabular}




\begin{tabular}{llll}
\hline Pendidikan & Pendidikan & Pendidikan & Pendidikan \\
Kewarganegaraan & Kewarganegaraan & Kewarganegaraan & Kewarganegaraan \\
Liberal & yang beragam & Kritis & Republik \\
\hline warga negara & yang membentuk & untuk lebih & \\
yang & masyarakat & memahami & \\
berpartisipasi & menerima & realitas \\
& pengakuan dan & masyarakat yang & \\
& mengambil bagian & tidak adil \\
& dalam bidang & \\
\hline
\end{tabular}

Sumber: Joel Westheimer yang dikutip oleh Grammes (2011, hal. 8).

Hal tersebut sesuai dengan pendapat Suharyanto (2013, hal. 202) bahwa Pendidikan Kewarganegaraan salah satunya berfungsi untuk mengembangkan dan membina kesadaran dan terhadap hubungan antara warga negara dengan sesama warga negara serta pendidikan pendahuluan bela negara agar mengetahui dan mampu melaksanakan dengan baik hak dan kewajiban sebagai warga negara. Lebih lanjut Suharyanto menjelaskan terdapatnya fungsi Pendidikan Kewarganegaraan untuk membekali peserta didik dengan pengetahuan dan kemampuan dasar berkenaan dengan hubungan antara warga negara dengan negara serta Pendidikan Pendahuluan Bela Negara (PPBN) agar menjadi warga negara yang dapat diandalkan oleh bangsa dan negara, dan secara umum bertujuan untuk membina Indonesia menjadi manusia yang taat pada Tuhan Yang Maha Esa. Oleh sebab, itulah wujud dari warga negara yang baik dalam versi Indonesia.

Makna moral dari fungsi Pendidikan Kewarganegaraan tersebut yang merujuk pada gagasan budaya "menjadi warga negara yang baik", memiliki dua makna. Pertama, terdapatnya suatu harapan bahwa individu dapat mematuhi hukum dan memenuhi kewajiban hukum yang diisyaratkan yang terkait dengan menjadi warga negara. Misalnya, warga negara yang baik bukanlah penjahat, teroris, atau pemberontak yang bermaksud menjatuhkan negara. Makna kedua yaitu mengacu pada harapan budaya dari tindakan yang sesuai secara moral, sehingga warga negara yang baik harus digambarkan sebagai seseorang yang mampu berpartisipasi dalam asosiasi sukarela; seseorang yang secara sukarela membantu komunitasnya; dan seseorang yang umumnya berperilaku dengan cara yang lebih baik bagi masyarakat. Dengan kata lain, kewarganegaraan lebih dari sekadar keadaan; itu juga merupakan tindakan atau proses melakukan perilaku (Janoski \& Compion, 2015, hal. 660).

Hasil penelitian di Malaysia, dalam rangka mengejawantahkan warga negara yang baik. Pendidikan Tinggi diberikan kepercayaan untuk memfasilitasi pengembangan warga negara melalui lembaga dengan menghasilkan warga negara yang menjadi tenaga kerja yang berpengetahuan luas untuk pembangunan sosial-ekonomi jangka panjang negara tersebut bahkan menghasilkan peserta didik yang memiliki identitas sipil dan kewarganegaraan global yang dapat menghadapi kompleksitas pembangunan bangsa terutama dalam hubungan etnis (Yusof et al., 2014, hal. 610).

Lebih lanjut menurut Janoski \& Compion (2015, hal. 660), akibat dari makna warga negara yang baik tersebut, setiap warga negara diberikan keleluasaan untuk membuat pilihan individu tentang caranya untuk menjadi warga negara. Misalnya, membayar pajak bukan masalah sederhana warga negara yang memenuhi kewajiban dengan menulis cek kepada pemerintah. Ini juga melibatkan pengambilan banyak keputusan tentang alternatif perpajakan, seperti berinvestasi dalam obligasi daerah bebas pajak atau akun pajak tangguhan lainnya, menghindari pajak sama sekali dengan menyembunyikan uang di rekening luar negeri, memprotes pajak, dan sebagainya. Dengan kata lain, hak dan kewajiban kewarganegaraan tidak dapat direduksi menjadi satu titik kecil dalam spektrum perilaku. 
Di Kazakhstan, pendidikan semacam ini diberikan melalui aktivitas sipil dan pendidikan patriotik yang diberikan kepada pemuda dalam kerangka untuk mengembangkan strategis intelektual negara. Dengan adanya pendidikan tersebut, diharapkan dapat: (1) memberikan bantuan informasi untuk pendidikan sipil mengenai kursus integratif, modul pelatihan, program-program praktik yang berorientasi pedagogi, yaitu program pendidikan untuk memajukan patriotisme; (2) memberikan pengembangan kriteria untuk pendidikan sipil dan alat diagnostik untuk melacak dinamika kesadaran sipil utama warga negara masa depan yang dibutuhkan; (3) mengembangkan dan memperkuat model pendidikan sipil di sekolah menengah dan tinggi dengan mempertimbangkan kekhususan regional; (4) membuat dan mengembangkan situs web patriotik tentang simbol-simbol nasional untuk memperkuat nasionalisme dan patriotisme warga negara sipil; dan (5) melibatkan dan menerapkan keterampilan kreatif dan inovatif untuk anak muda, karena negara perlu untuk membentuk suatu gagasan nasional bersama (Tolen et al., 2014, hal. 4683). Begitu juga yang terjadi di Rusia, pemerintah memperkuat agenda kohesi negara dengan wacana pendidikan patriotik (Janmaat \& Piattoeva, 2007, hal. 257).

Namun dalam perkembangannya, dalam penelitian Negedu \& Atabor (2015) diungkapkan bahwa nasionalisme sebagai konsep telah disalahartikan agar sesuai dengan kategori mental warga negara suatu negara dan karena gagasan rasa kebangsaan direndahkan, maka warga negara kehilangan makna patriotisme dalam arti yang sangat jelas. Hal tersebut disebabkan, patriotisme telah hancur dibakar karena tidak memiliki nilai kepraktisan. Bahkan untuk berbicara patriotisme dengan gagasan mengenai kebangsaan yang tidak lebih dari sekadar isapan jempol dari pemikiran seseorang. Warga negara harus diajari untuk melepaskan diri dari fondasi/tradisi yang lemah dan rusak serta merangkul keberlanjutan dalam arah positif. Oleh karena, gagasan patriotisme sebagai cabang dari nasionalisme akan mungkin terjadi apabila nilai-nilai tertanam dalam benak warga negara sejak dari awal (Negedu \& Atabor, 2015, hal. 74).

Hasil perhitungan statistik yang dilakukan terhadap 400 orang peserta didik dengan mengembangkan instrumen yang disesuaikan dengan Pasal 4 Surat Keputusan Dirjen Dikti No. 43/Dikti/2006 ditentukan bahwa Dasar Substansi Kajian Mata Kuliah Pendidikan Kewarganegaraan diperoleh informasi bahwa:

Tabel 2.

Hasil Perhitungan Uji Hipotesis Berdasarkan Substansi PKn

\begin{tabular}{ll}
\hline Substansi & \multicolumn{1}{c}{ Uji Hipotesis } \\
\hline Pendidikan Kewarganegaraan & Cinta tanah air 0.090>0,05 \\
& Sadar berbangsa dan bernegara 0,056>0,05 \\
& Setia terhadap Pancasila 0,054>0,05 \\
& Rela berkorban untuk bangsa dan bernegara 0,220 $>0,05$ \\
& Kemampuan awal bela negara 0,067>0,05 \\
& Semangat untuk mewujudkan negara yang berdaulat, adil, dan makmur \\
& $0,119>0,05$ \\
\hline
\end{tabular}

Sumber: Tim Peneliti, 2019

Dari tabel di atas dapat di jelaskan, dengan menggunakan alpa 0,05 maka diperoleh perhitungan bahwa terdapat pengaruh Pendidikan Kewarganegaraan terhadap nilai-nilai bela negara antara lain nilai cinta tanah air oleh sebab signifikan lebih dari alpa yaitu 0,090 $>0,05$, nilai kesadaran berbangsa dan bernegara 0,056 >0,05, nilai rela berkorban untuk bangsa dan negara 0,22>0.05, nilai kemampuan awal bela negara 0,067 $>0,05$, dan nilai semangat untuk mewujudkan negara yang berdaulat, adil, dan makmur 0,119 >0,05. 
Berdasarkan hasil perhitungan tersebut, dapat diperoleh informasi bahwa pengetahuan warga negara dalam hal ini peserta didik bertambah oleh sebab mereka telah mendapatkan materi tersebut 12 (dua belas) tahun mulai dari sekolah dasar sampai sekolah menengah atas. Namun, besaran setiap indikator bela negara memiliki besaran yang berbeda karena peserta didik memperoleh informasi yang berbeda dari pendidik yang mengampu mata kuliah Pendidikan Kewarganegaraan. Hal tersebut sesuai dengan penelitian Oyetade (2012, hal. 145) bahwa hasil kualitatif mengungkapkan bahwa siswa menjadi lebih berpengetahuan tentang banyak masalah kewarganegaraan dan sikap yang sama-sama memanifestasikan yang dapat digambarkan sebagai keadaan positif terhadap konsep dasar.

Namun, dalam tataran praktik pembelajaran masih di dominasi oleh teacher center yang berpusat kepada dosen. Bahkan kegiatan pembelajaran cenderung monoton dengan penggunaan metode ceramah, tugas isian buku paket, dan terikat dengan ruang kelas. Padahal menurut Oyetade (2012, hal. 150), dalam membina kesadaran bela negara pada diri peserta didik harus dilakukan dengan menggunakan pendekatan partisipatif lebih efektif daripada metode pengajaran konvensional dalam mendorong perolehan pengetahuan siswa tentang isu-isu kewarganegaraan dan juga mengungkapkan bahwa efek utama perlakuan terhadap sikap tidak signifikan.

Diperkuat dengan hasil wawancara yang dilakukan dengan peserta didik dan dosen, bahwa pengaruh Pendidikan Kewarganegaraan terhadap bela negara yaitu.

1. Pengaruhnya sangat signifikan, karena pada dasarnya nilai bela negara terdapat pada Pendidikan Kewarganegaraan yaitu sebagai sarana pembentukan karakter pribadi bagi setiap peserta didik. Namun demikian, masih terdapat kelemahan berupa kejelasan kurikulum dalam tahapan implementasinya. Hal ini disebabkan hampir setiap materi Pendidikan Kewarganegaraan sangat teoretis kecuali materi tentang geopolitik dan geostrategi. Keadaan yang hampir serupa juga terjadi dalam kurikulum dan buku teks di Pakistan, di mana Pendidikan Kewarganegaraan menjadikan dan mempromosikan bagaimana kewarganegaraan yang eksklusif dan pasif. Bahkan peserta didik di Pakistan, memperoleh pengetahuan dan mempelajari beberapa nilai penting di sekolah, mereka tidak belajar keterampilan (pemecahan masalah, pengambilan keputusan) dan nilai-nilai (kewarganegaraan, kesadaran kritis) yang diperlukan untuk partisipasi efektif dalam kehidupan demokratis (Dean, 2005, hal. 35). Selain itu, dalam memberikan penjelasan berupa contoh, pengajar menghadapi kesulitan dalam memberikan contoh baik yang disebabkan peserta didik sudah mendapatkan informasi terlebih dahulu dari media sosial. Keadaan ini sama persis dengan penelitian Chikwe (2012, hal. 1) bahwa peserta didik mempelajari teks kewarganegaraan yang berbeda dan dapat menilai nilai-nilai mereka dan orang lain secara berbeda. Mereka belajar untuk merasa tidak berdaya, teralienasi, memalukan, marah, dan dikhianati daripada diberdayakan.

Dengan adanya ilustrasi yang demikian, maka sangat perlu untuk melakukan reformulasi materi apa saja dalam Pendidikan Kewarganegaraan yang dapat menggugah peserta didik memiliki pemahaman yang holistik tentang pendidikan pendahuluan bela negara. Hal tersebut sangat logis, mengingat pelaksanaan Pendidikan Kewarganegaraan di perguruan tinggi tidak memiliki tujuan untuk mengajarkan setiap peserta didik dari program studi menjadi ahli Pendidikan Kewarganegaraan. Akan tetapi, dengan dilaksanakannya Pendidikan Kewarganegaraan bagi peserta didik, maka diharapkan pada proses dan akhir perkuliahan dapat menjadi warga negara yang baik berupa kepemilikan rasa cinta tanah air, rela berkorban, sadar berbangsa dan bernegara, setia terhadap Pancasila sebagai ideologi negara, memiliki kemampuan awal bela negara baik secara fisik maupun non-fisik (Gredinand, 2017, hal. 25).

2. Pendidikan Kewarganegaraan di perguruan tinggi cukup signifikan berpengaruh terhadap pendidikan pendahuluan bela negara apabila diberikan penyadaran maka antusiasme peserta 
didik untuk mempertahankan Negara Kesatuan Republik Indonesia ini semakin baik. Hal tersebut dikuatkan oleh Tamba (2017, hal. 338) yang menjelaskan bahwa suatu bangsa memang harus dikuatkan rasa nasionalismenya untuk melindungi dan membela negaranya. Akan tetapi, hal tersebut masih menghadapi kendala, di mana pendidik yang mengampu mata kuliah Pendidikan Kewarganegaraan masih diberikan kepada mereka yang tidak memiliki keahlian pada bidangnya. Mereka mengampu mata kuliah Pendidikan Kewarganegaraan disebabkan kekurangan SKS atau sekadar menunaikan perkuliahan.

Hal tersebut akan sangat berpengaruh terhadap pendidikan pendahuluan bela negara yang dipahami oleh peserta didik. Oleh sebab, setiap pendidik yang tidak memiliki keahlian dalam Pendidikan Kewarganegaraan akan memberikan penjelasan tentang makna-makna dari materi mata kuliah tersebut sesuai dengan keilmuannya masing-masing. di Universitas Pendidikan Indonesia, agar penyelenggaraan Pendidikan Kewarganegaraan sesuai dengan tujuan sebagai mata kuliah wajib umum, maka sudah direncanakan dan diupayakan bahwa untuk perekrutan tenaga pendidikan harus berasal dari sarjana Pendidikan Kewarganegaraan dan magister Pendidikan Umum dan Karakter yang memiliki konsentrasi pada mata kuliah umum bukan disiplin ilmu.

3. Implementasi Pendidikan Kewarganegaraan sebagai pendidikan pendahuluan bela negara tergantung dari perilaku peserta didik itu sendiri. Hal tersebut sesuai dengan hasil penelitian bahwa persiapan peserta didik sekolah untuk kewarganegaraan sering diabaikan dan tidak ditangani dengan baik (Dean, 2005, hal. 51). Keadaan seperti ini akan berdampak pada proses aktualisasi peserta didik setelah kembali pada kehidupan masyarakat. Apabila materi-materi yang disampaikan pada perkuliahan Pendidikan Kewarganegaraan hanya mengulang materi dari tingkat sekolah dasar sampai sekolah menengah atas, maka peserta didik akan mengalami kejenuhan. Hal ini dibuktikan dengan hasil wawancara yang dapat ditarik simpulan bahwa materi yang ada sama persis dengan materi yang ada pada tingkat sekolah dasar dan menengah. Padahal yang mereka butuhkan saat ini yaitu aktualisasi dari pengetahuan yang sudah mereka miliki agar dapat menjadi warga negara yang baik sesuai kehendak dari negara.

Selain itu, proses perkuliahan yang mengandalkan buku paket/modul memberatkan peserta didik karena mereka tidak mendapatkan gambaran dari pendidikan pendahuluan bela negara selain materi yang sangat teoretis dan penuh dengan hafalan. Akhirnya, ini akan kembali pada kemampuan pendidik untuk mengejawantahkan bagaimana pendidikan pendahuluan bela negara dapat dipahami dari materi yang sudah dibuat agar mampu dimaknai oleh peserta didik sebagai wujud nyata dari bela negara seperti yang terdapat pada Pasal 9 Undang-Undang Nomor 3 tahun 2002 tentang Pertahanan Negara.

4. Dapat memupuk kesadaran akan pentingnya membela dan mencintai bangsa sendiri. Hal ini menurut Chikwe (2012, hal. 21) disebabkan Pendidikan Kewarganegaraan memiliki janji untuk memperluas tujuan sempit kewarganegaraan tradisional ke perspektif global, karena kapasitas terorganisir pendidikan kewarganegaraan dan sekolah pada umumnya dalam mengkomunikasikan cita-cita sipil.

Dari uraian di atas, dapat dimengerti bahwa kendala dalam implementasi pendidikan pendahuluan bela negara untuk warga negara sipil yang diselenggarakan melalui pendidikan kewarganegaraan antara lain (1) kebijakan penyelenggaraan Pendidikan Kewarganegaraan masih diserahkan kepada kampus/universitas masing-masing dalam pelaksanaannya dan pengembangannya. Padahal, mata kuliah tersebut "plat merah" yang semestinya harus menjadi gambaran dari kehendak negara untuk menciptakan dan membina warga negara yang memiliki rasa nasionalisme dan patriotisme agar dapat mempertahankan negara dari berbagai ancaman, 
tantangan, hambatan, dan gangguan; (2) materi-materi Pendidikan Kewarganegaraan dalam penyajiannya masih teoretis dan sangat menekankan aspek kognitif berupa hafalan. Meski pemerintah sudah secara resmi membuat buku khusus tentang Pendidikan Kewarganegaraan, tetapi pada praktiknya hampir setiap kampus/universitas/perguruan tinggi mengembangkan kembali materi tersebut. Namun sayangnya, materi yang dikembangkan masih sangat teoretis; (3) proses pembelajaran Pendidikan Kewarganegaraan masih bersifat klasikal dan jika terdapat tambahan kegiatan pun hanya berupa presentasi dari materi yang sudah terdapat pada buku paket/modul yang sudah disiapkan; (4) evaluasi yang belum jelas, juga menjadi masalah yang belum tertangani secara baik. Hal tersebut meski sudah dilakukan melalui ujian berbasis komputer, tetapi peserta didik beranggapan bahwa tes yang diselenggarakan hanya menguji pengetahuan saja belum dapat menguji afektif apalagi psikomotor; (5) tenaga pendidik yang masih terbatas kehadirannya di kelas dan mengajarkan materi sesuai dengan keahliannya masing-masing pun menjadi masalah yang belum mendapatkan solusi yang bersifat nasional. Hal tersebut menjadi masalah tersendiri dalam penyelenggaraan Pendidikan Kewarganegaraan di perguruan tinggi Indonesia secara mayoritas. Oleh sebab, Pendidikan Kewarganegaraan dianggap mata kuliah hafalan yang dapat diajarkan oleh siapa saja, padahal mata kuliah tersebut merupakan mata kuliah kehendak negara untuk menciptakan dan membina warga negara sipil dalam kerangka pendidikan pendahuluan bela negara.

\section{Simpulan}

Berdasarkan temuan di atas, dapat disimpulkan bahwa Pendidikan Kewarganegaraan dalam fungsinya sebagai pendidikan pendahuluan bela negara memberikan kontribusi yang cukup signifikan. Hal tersebut dapat dilihat dari hasil perhitungan statistik di mana materi-materi Pendidikan Kewarganegaraan yang terdapat di perguruan tinggi memiliki nilai signifikan lebih besar dari alpa 0,05 . Namun, dari hasil wawancara dengan beberapa dosen pengampu masih terdapat beberapa hal yang harus diperjelas dalam implementasinya seperti kurikulum, pengampu mata kuliah Pendidikan Kewarganegaraan, materi yang sama dengan sekolah menengah, metode pembelajaran yang harus menekankan tahapan pendidikan pendahuluan bela negara yang tepat.

Selanjutnya dikemukakan beberapa saran sebagai berikut. Pendidikan Kewarganegaraan dalam fungsinya sebagai pendidikan pendahuluan bela negara harus diberikan kejelasan struktur kurikulum agar rasional untuk diimpelemntasikan sebagai suatu kegiatan yang dapat mempererat keterikatan warga negara dengan negara. Hal tersebut dapat dilihat dari nilai-nilai yang harus dikembangkan dalam bela negara seperti nasionalisme dan patriotisme. Akan tetapi, hal tersebut masih akan sangat sulit mengingat pelaksanaan Pendidikan Kewarganegaraan di berbagai kampus di Indonesia masih belum menemukan keseragaman konsep dan praktik pengajaran. Keadaan tersebut menjadi lebih rancu saat pemerintah menyerahkan pelaksanaan Pendidikan Kewarganegaraan kepada kampus dalam pengembangannya, padahal mata kuliah tersebut merupakan "plat merah" yang menjadi keharusan warga negara untuk tahu, terampil, dan memiliki watak yang baik melalui mata kuliah tersebut. Dengan demikian, perlu dirumuskan ulang mengenai paradigma Pendidikan Kewarganegaraan di perguruan tinggi agar memiliki kejelasan dalam pencapaian tujuan, apakah akan mengarah pada budaya tradisional (nilai-nilai nasionalisme dan patriotisme yang dapat memperkuat bela negara) atau paradigma baru ala Amerika Serikat yang mengarahkan pelaksanaan Pendidikan Kewarganegaraan pada pendidikan demokrasi. Selain itu, harus juga dipikirkan bagaimana implementasi Pendidikan Kewarganegaraan baik dari sisi materi, pendidik, metode, sampai pada evaluasi agar betul-betul dapat diwujudkan sebagai pendidikan pendahuluan bela negara untuk warga negara sipil khususnya para pemuda penerus bangsa.

\section{Referensi}

Anggoro, K. (2003). Keamanan nasional, pertahanan negara, dan ketertiban umum. Seminar Pembangunan Hukum Nasional VIII, 1-10. 
Asep Dahliyana, Encep Syarief Nurdin, Dasim Budimansyah, Ace Suryadi. Pendidikan pendahuluan bela negara melalui pendidikan kewarganegaraan

Chikwe, M. (2012). Civic education and global citizenship : A Deweyan perspective. Journal of Peace Education and Social Justice, 6(1), 1-25.

Dean, B. L. (2005). Citizenship education in Pakistani schools: Problems and possibilities. International Journal of Citizenship and Teacher Education, 1(2), 35-55.

Enu, D. B. (2017). Civic education as catalyst for the sustenance of true federalism in nigeria. International Journal of Advanced Research in Public Policy, Social Development and Enterprise Studies, 2(1), 36-46.

Grammes, T. (2011). Nationalism, patriotism, citizenship and beyond - Editorial. Journal of Social Science Education, 10(1), 2-11.

Gredinand, D. (2017). Application of state defense education in colleges. Strategi Pertahanan Darat, 3(2), 127.

Hwang, I. (2018). Militarising national security through criminalisation of conscientious objectors to conscription in South Korea. Critical Studies on Security, 6(3), 296-311. https://doi.org/10.1080/21624887.2018.1424986

Janmaat, J. G., \& Piattoeva, N. (2007). Citizenship education in Ukraine and Russia: Reconciling nationbuilding and. Comparative Education, 43(4), 527-552. https://doi.org/10.1080/03050060701611920

Janoski, T., \& Compion, S. (2015). Citizenship, sociological aspects of. In International Encyclopedia of the Social \& Behavioral Sciences: Second Edition (Second Edi, Vol. 3, Issue 2011). Elsevier. https://doi.org/10.1016/B978-0-08-097086-8.32015-3

Kosnik, M. (2017). Conscription in the twenty-first century: Do reinforcements equal security? Comparative Strategy, 36(5), 457-467. https://doi.org/10.1080/01495933.2017.1379839

Kwon, I. (2000). A feminist exploration of military conscription: The gendering of the connections between nationalism, militarism and citizenship in South Korea. International Feminist Journal of Politics, 3(1), 26-54. https://doi.org/10.1080/713767489

Lukman, A. A., \& Audu, H. (2014). Promoting sustainable development in Nigeria : Via civic education. Journal of Education and Practice, 5(34), 119-126.

Mellors, C., \& McKean, J. (1984). The politics of conscription in Western Europe. West European Politics, 7(3), 25-42. https://doi.org/10.1080/01402388408424485

Nair, E. (1995). Nation-building in Singapore : Psychological annalysis. Journal of Human Values, 1(1), 93-102.

Negedu, I., \& Atabor, A. (2015). Nationalism in Nigeria: A case for patriotic citizenship. American International Journal of Contemporary Research, 5(3), 74-79.

Oyetade, E. M. (2012). Developing knowledge and attitudes of civic education in students for sustainable development: A case study of Lagos State Nigeria. International Journal of Humanities and Social Science, 2(4), 145-151.

Purwaningsih, E. (2005). Pembinaan kesadaran bela negara sebagai salah satu upaya mencegah disintegrasi bangsa (Studi kasus di Provinsi Nanggroe Aceh Darussalam). Universitas Indonesia.

Randall, D. (2017). Making citizens : How American universities teach civics. National Association of Scholar.

Sigauke, A. T. (2019). Citizenship and Citizenship Education in Zimbabwe: A Theoretical and Historical Analysis. In The Palgrave Handbook of Citizenship and Education (Vol. 2, Issue 4, pp. 1-16). Springer International Publishing. https://doi.org/10.1007/978-3-319-67905-1_42-1

Suharyanto, A. (2013). Peranan pendidikan kewarganegaraan dalam membina sikap toleransi antar siswa. Jurnal Ilmu Pemerintahan Dan Sosial Politik 1, 1(2), 192-203.

Tamba, M. A. (2017). Peran pembelajaran pendidikan kewarganegaraan dalam menumbuhkan sikap bela negara. Prosiding Seminar Nasional Tahunan Fakultas IImu Sosial Universitas Negeri Medan, 1(1), 333338.

Tolen, Z., Tulenova, S., Assyltaeva, E., \& Aitymbetov, N. (2014). Formation of civil and patriotic education of youth in Kazakhstan. Procedia - Social and Behavioral Sciences, 116, 4859-4863.

https://doi.org/10.1016/j.sbspro.2014.01.1038 
Yusof, D. M., Zakariya, H., \& Shahdan, A. (2014). Higher education and civic development in Malaysia.

Proceedings of SOCIOINT14- International Conference on Social Sciences and Humanities, September, 604-611. 